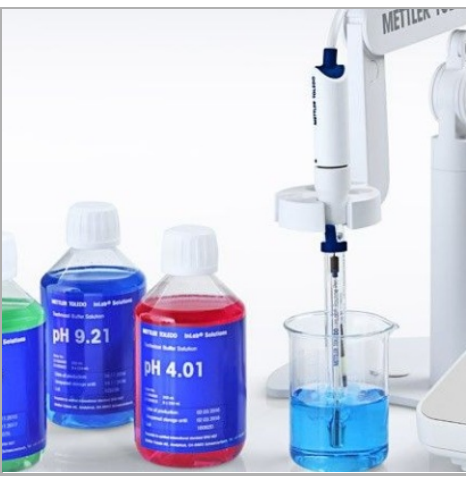

JUN 03, 2020

\section{open Әaccess}

DOI:

dx.doi.org/10.17504/protocol s.io.bfypjpvn

Protocol Citation: Neilier Junior 2020. Phosphate Buffered Saline (PBS). protocols.io

https://dx.doi.org/10.17504/p rotocols.io.bfypjpvn

License: This is an open access protocol distributed under the terms of the Creative Commons Attribution License, which permits unrestricted use, distribution, and reproduction in any medium, provided the original author and source are credited

Protocol status: Working We use this protocol and it's working

Created: May 05, 2020

Last Modified: Jun 03, 2020

PROTOCOL integer ID:

36591

Keywords: $\mathrm{pH}$, HendersonHasselback, Biochemistry, Molecular Biology

\section{(3) Phosphate Buffered Saline (PBS)}

(7) 1 collection

Neilier Junior ${ }^{1}$

${ }^{1}$ Universidade Federal de Viçosa

Neilier Junior

Universidade Federal de Viçosa, University of Manitoba

\section{ABSTRACT}

A buffer solution has the function of resisting changes in $\mathrm{pH}$ even when adding powerful acids or bases. However, in the physiological environment the buffered system also provides cofactors for enzymatic reactions, critical salts and even essential nutrients for cells and tissues. Therefore, when trying to reproduce biological conditions in vitro, we must make the appropriate choice of the buffer. After all, it will provide the appropriate medium in which reactions will occur.

\section{MATERIALS}

- Distilled Water

- $\mathrm{pH}$ Meter (sensitive)

- $\mathrm{NaCl}$

- Potassium Phosphate Buffer

- $\mathrm{Na}_{2} \mathrm{HPO}_{4}$

- $\mathrm{KH}_{2} \mathrm{PO}_{4}$

\section{SAFETY WARNINGS}

Wear personal protective equipment: gloves, lab coat and mask.

\section{BEFORE START INSTRUCTIONS}

Organize your workspace.

Make sure all solutions and equipment are available.

\title{
Phosphate Buffered Saline (PBS)
}


Note

\section{(). 7.4}

$150 \mathrm{mM} \mathrm{NaCl}$

$10 \mathrm{mM}$ Potassium Phosphate buffer

\section{Prepare \ 1 LPBS by dissolving \ $8.7 \mathrm{~g} \mathrm{NaCl}$, \ $1.82 \mathrm{~g} \mathrm{~K} 2 \mathrm{HPO} 4 \cdot 3 \mathrm{H} 2 \mathrm{O}$ and \\ \ $0.23 \mathrm{~g} \mathrm{KH} 2 \mathrm{PO} 4$ in $\triangle 1 \mathrm{~L}$ distilled water}

1.1 A variation of PBS can also be prepared as follows:

\begin{tabular}{l} 
[M] 137 millimolar $(\mathrm{mM}) \mathrm{NaCl}$ \\
\hline [M] 2.7 millimolar $(\mathrm{mM}) \mathrm{KCl}$ \\
\hline [M] 10 millimolar $(\mathrm{mM}) \mathrm{Na} 2 \mathrm{HPO} 4$ \\
\hline [M] 1.76 millimolar $(\mathrm{mM}) \mathrm{KH} 2 \mathrm{PO} 4$ \\
\hline
\end{tabular}

2 Adjust the $\mathrm{pH}$ before use. 